\title{
The Social Profile, Constraints, and Its Impact on Swine Herd Size in Tra Vinh Province, Vietnam
}

\author{
N. H. Qui, B. Guntoro*, \& S. P. Syahlani \\ Faculty of Animal Science, Universitas Gadjah Mada, \\ Jalan Fauna 3, Bulaksumur, Yogyakarta 55281, Indonesia \\ *Corresponding author: budiguntoro@ugm.ac.id \\ (Received 12-04-2020; Revised 02-07-2020; Accepted 06-07-2020)
}

\begin{abstract}
The objective of this study was to describe social profile, constraints of swine farmers, and its impact on swine herd size in Tra Vinh Province. This study was conducted in Tra Vinh Province, one of the provinces in Mekong delta, Vietnam. A total of $\mathbf{1 2 0}$ swine farmers selected from small swine farms to commercial swine farms were surveyed with information gathered on 11,466 swine. All of the swine farmers in this study were purposively chosen and interviewed with the questionnaires for data collection. All swine farmers have kept at least 1 swine per farm or had experience at least 1 year for raising and trading swine. The results showed that the majority of farmers were males $(57.5 \%)$, with the age range of $20-40$ years old $(47.5 \%)$, having more than 10 years of experience $(52.5 \%)$, having 1-3 members in the family (87.1\%), $85 \%$ of farmers focused on farm, farmers having livestock farming plus cropping accounted for $55.8 \%$, and farmers having medium farm size with an average of $95-96$ heads/farm. In addition, there were 4 constraints that farmers confirmed, i.e., capital $(31.6 \%)$, disease outbreak $(75 \%)$, low bargaining power $(40 \%)$, and the fluctuation of feed price $(59.16 \%)$. Moreover, experience $(p<0.01)$, education $(p<0.01)$, disease outbreak $(p<0.05)$, and the fluctuation of feed price $(p<0.05)$ had a strong influence on swine herd. It could be concluded that farmers having higher experience and education kept a larger number of swine than others. In contrary, when disease outbreak and the fluctuation of feed price emerge, farmers tended to control their swine herd size.
\end{abstract}

Keywords: social profile, constraints, swine production

\section{INTRODUCTION}

Swine is one of the most important livestock in Vietnam, which has mostly been distributed to human nutrient of Vietnamese and played a crucial role in total meat consumption. Before African Swine Fever (ASF) outbreak, swine production contributed about $78 \%$ of the total meat production in Vietnam annually (GSO, 2016). In the first months of 2019, ASF outbroke in Vietnam culled more than $20 \%$ swine population (FAO, 2019).

There are significantly different knowledge gaps between swine raisers and also between the characteristics of smallholders about various swine production systems, from both social-economic and productivity perspective (Ieda et al., 2015). Social demographic characteristics such as age, gender, family member, formal education, experience, and constraints were recorded as factors affecting animal production (Ibrahim et al., 2013; Odhiambo et al., 2019; Phiri, 2012). Farmers who have higher knowledge or higher education can control mating and keeping livestock in the farm efficiently and they also can improve their management strategies (Roessler et al., 2016). There are a lot of constraints faced by the farmers, i.e., investment, poor animal feed, animal resources, poor marketing infrastructure for livestock products, less access to loan, and disease which also can be found as a negative impact on livestock production (Haftu et al., 2014; Hayat et al., 2017; Menbere, 2014). In addition, most small swine farmers in Vietnam, especially in the North of Vietnam, used traditional feeds such as rice bran and agricultural by-products (Ieda et al., 2015). There was a fluctuation in feed price when farmers bought concentrates, which were made from imported ingredients. The production constraints, such as feed cost and lack of knowledge about swine health, might hinder the enhancement of swine productivity (Mekuriaw \& Asmare, 2014). Moreover, low power in bargaining position was also one of constraints on the farm. Farmers had to improve their farming scale to have more power in bargaining positions (MalakRawlikowska et al., 2019).

In previous studies, the improvement of swine herds has not only been distributed to human nutrition but also reduced the purchasing of livestock products from abroad (Fualefac et al., 2014). There were a lot of researches about nutrition (Pomar \& Remus, 2019; Van Cuong et al., 2016), technologies (Benjamin \& Yik, 2019; Thi Ly et al., 2016), genetics (Hong Anh et al., 2014; Wang et al., 2017), and its application in swine farm but there 
was a small number of researches focusing on farmer profile, constraints, and swine herd size during ASF outbreak, especially in Tra Vinh Province. As a livestock structure in Vietnam, swine is also the dominant livestock in Tra Vinh where agriculture is a majority of jobs and by-products from agriculture are suitable for developing animal husbandry. In addition, Tra Vinh Province is one of the poorest provinces in Mekong delta where the researches should be more focused. The profile of swine farmers was not mentioned during ASF outbreak, swine herd size was continuously changed by various risks on farm. Because of ASF, a lot of swine have been culled and a lot of farmers confirmed that they have gone out of business. In case of ASF context in Vietnam, it is necessary to find out the information of farmer profiles, constraints, and the number of swine on farm. Moreover, government or other organizations cannot help swine farmers when the disease outbreak or any risks emerge on the farm if there is no information relating to swine farmers.

The aims of this study were to identify the profiles of swine farmers such as age, gender, family member, formal education, experience in raising swine, occupation, type of farming, and the current constraints as well as the effect of these factors on swine herd size.

\section{MATERIALS AND METHODS}

\section{Study Area}

Tra Vinh is one of 13 provinces in Mekong delta and was known as one of the poorest provinces in Mekong delta, Vietnam. Tra Vinh Province consists of nine districts. However, the study was conducted in three districts of Tra Vinh Province, namely Cang Long District, Cau Ke District, and Tieu Can District where swine populations were much higher than in the other districts. In addition, the swine farming activities in these districts were the busiest which could display the status of all.

\section{Data Collection}

The surveys were conducted from $5^{\text {th }}$ January to $29^{\text {th }}$ January, 2020 to get data with two levels which were a household-level and a farm-level survey, which were presented in case of ruminant livestock (Lesnoff et al., 2010) and in case of swine production (Ieda et al., 2015). The survey was conducted in the local language (Vietnamese).

A household-level survey was designed to collect data about the social profile such as gender, age, family member, experience, formal education, occupation, and constraints. Face-to-face interviews and questionnaires were used to collect data. A farm-level survey was designed to obtain data on ownership and type of farming.

A purposive sampling method was used to select samples from the total of small swine farmers to give a sample size of 120 by following information from the government staff and animal feed seller. Farmers had to own at least 1 swine on their farm and had experience at least 1 year for raising and trading of swine. Because of the unknown population of pig farmers during the context of ASF, the respondents were chosen by following the formulation of Tabachnick \& Fidell (1996) as below:

$$
\mathrm{N}=50+8^{*} \mathrm{n}
$$

where $\mathrm{N}$ was the number of respondents of the study and $\mathrm{n}$ is independent variables of the study.

In this study, there were 7 independent variables, i.e., gender, age, family member, experience, formal education, occupation, and constraint. It was clear that there were 106 respondents selected according to the above formulation. However, to make sure that the number of respondents was correct, we chose 120 respondents (40 respondents per district) for this study. The 120 respondents were face-to-face interviewed following the questionnaires. The sections of the questionnaire included socio-characteristics and the swine herd size of small swine farmers.

\section{Data Analysis}

Data were analyzed by STATA 14.0 and Excel 2013. Descriptive statistics were illustrated for all of variables in this study. Ordinal Logistic Regression (OLR) was used to analyze the influence of social profile and constraints on the number of swine in the farm. Values of $p<0.05$ and $p<0.01$ were considered statistically significant.

OLR is one kind of logistic regression models in which the response variable has more than two categories having natural order or rank. OLR may be useful when we are analyzing a categorical dependent variable as a function of one or more independent variables being the dependent variable has more than two outcomes (Lind et al., 2018). The function of OLR consists of $Y$ (dependent variables with $\mathrm{j}=1,2,3, \ldots, \mathrm{J}$ ) and $\mathrm{X}$ (independent variables). Pr is the probability of the number of swine and can be illustrated as follow:

$\operatorname{logit}[\operatorname{Pr}(Y \leq j)]=\alpha j+(\beta 1 X 1+\beta 2 X 2+\ldots .+\beta n X n), j=1,2,3$, $\ldots, \mathrm{J}-1$

where $\operatorname{Pr}(\mathrm{Y}=\mathrm{j})$ was probability of dependent variable, $\alpha$ was an intercept $\left(\alpha_{1} \leq \alpha_{2} \leq \alpha_{3} \leq \ldots \leq \alpha_{\mathrm{J}-1}\right)$, and $\beta \mathrm{n}$ was the vector of independent variables $X_{n}$.

ORL showed the influence between the dependent variable (swine herd size) and multiple independent variables (gender, age, family member, experience, formal education, occupation, type of farming, and constraint) which are presented in Table 1 and Table 2.

The relationship between social profile constraints and the number of swine were explored through ORL. The social profile was modeled as a demographic factor that impacts on the number of swine keeping on the farm. The number of swine was respected to be changed by a certain factor if any independent variables increase by one unit.

It was expected that the increase of experience in raising swine and formal education of farmers could lead to an increase of swine herd size. Besides, the farmers could face more constraints if they owned more swine. 
Table 1. Operational definition for the study (Social profile)

\begin{tabular}{|c|c|c|}
\hline Variables & Description & Type of measurement \\
\hline \multicolumn{3}{|l|}{ Dependent variable } \\
\hline The number of swine & The number of swine with level scale & $\begin{array}{l}\text { Categorical }(1=1-10 \text { swine, } 2=11-50 \text { swine, } 3=51- \\
100 \text { swine, } 4=\text { more than } 100\end{array}$ \\
\hline \multicolumn{3}{|l|}{ Independent variables } \\
\hline Gender & Gender of the farmers who are raising swine & Dummy (1= Male, $0=$ Female) \\
\hline Age & Age of the farmers in the year & $\begin{array}{l}\text { Categorical }(1=20-40 \text { years old, } 2=41-60 \text { years old, } \\
3=\text { more than } 60 \text { years old })\end{array}$ \\
\hline Family member & The number of members in family & Categorical $(1=1-3$ people, $2=4-6$ people $)$ \\
\hline Experience & $\begin{array}{l}\text { Experience of the farmers who have practiced } \\
\text { on swine farm }\end{array}$ & $\begin{array}{l}\text { Categorical }(1=1-5 \text { years, } 2=6-10 \text { years, } 3=\text { more } \\
\text { than } 10 \text { years })\end{array}$ \\
\hline Formal education & The education of farmers in the school & $\begin{array}{l}\text { Categorical ( } 1=\text { primary school, } 2=\text { secondary } \\
\text { school, } 3=\text { high school, } 4=\text { bachelor })\end{array}$ \\
\hline Occupation & The main occupation of farmers & $\begin{array}{l}\text { Categorical ( } 1=\text { livestock farming, } 2=\text { farming and } \\
\text { business) }\end{array}$ \\
\hline Type of farming & Types of farming is applied & $\begin{array}{l}\text { Categorical }(1=\text { integrated agriculture aquaculture } \\
\text { system, } 2=\text { farming and cropping, } 3=\text { multifaceted })\end{array}$ \\
\hline
\end{tabular}

Table 2. Operational definition for the study (Constraint factors)

\begin{tabular}{ll}
\hline Constraints & Constraint that farmers face, is an access to loan \\
\hline Capital & Constraint that farmers face, is disease outbreak \\
$\begin{array}{l}\text { Disease outbreak } \\
\text { Low bargaining power }\end{array}$ & Farmers have low power in bargaining when selling hog \\
The fluctuation of feed price & Constraint that farmers face, is the fluctuation of feed price
\end{tabular}

\section{RESULTS}

\section{Social Profile of Swine Farmers}

The social profiles including gender, age, family member, experience, formal education, occupation, swine herd size, and type of farming of swine farmers in Tra Vinh Province where the majority of farmers who took care of their farm were male $(57.5 \%)$ while female accounted for $42.5 \%$. Most of swine farmers in Tra Vinh $(47.5 \%)$ were 20 to 40 years old and $35 \%$ were at the age of $41-60$ years old where $81.7 \%$ of family had 1 to 3 people who were able to join in swine production activities. There were $52.5 \%$ of farmers who had more than 10 years of experience in raising swine and 33.3\% with $5-10$ years of experience and $14.2 \%$ with $1-4$ years of experience. All of 120 swine farmers selected had formal education. The data showed that swine farmers having less than 10 swine per farm was only $5 \%$ and most farmers had an average of 95-96 swine heads/farm, and $85 \%$ of the farmers were focused on the farm business. Additionally, the highest percentage of the type of farming was livestock plus cropping at their farms which accounted for $55.8 \%$.

\section{The Constraints to Swine Production in Tra Vinh Province}

There were several limitations of raising swine in Tra Vinh Province, namely capital, disease outbreak, low bargaining power, and the fluctuation of feed price (Table 3). Most farmers state that disease outbreak is a serious constraint in their farm causing the increased mortality, loss of profit, and even gone out of business. Similarly, the fluctuation of feed price was declared by the farmers as a serious constraint in swine farming. The status of disease outbreak and fluctuation of feed price can force them to adjust the sizes of their swine herds. Low bargaining power and capital are the constraints that were focused by a few farmers.

\section{The Impact of Social Profile and Constraints on Swine Ownership}

Table 4 shows the positive effects of experience, formal education, disease outbreak, and the fluctuation of feed price. For experience of farmers, we could say that for a one unit increase in experience, from 1 to 3 , we expect a 1.1619 increase in log odds of being in a higher level of the number of swine, given all of the other variables in the model were held constant. For formal education, we could say that for a one unit increase in formal education (from 1 to 4 ), we expected a 1.9832

Table 3. The constraints of swine farmer in Tra Vinh Province, Vietnam

\begin{tabular}{lcc}
\hline Constraints & Farmer & Percentage $(\%)^{*}$ \\
\hline Capital & 38 & 31.67 \\
Disease outbreak & 90 & 75.00 \\
Low bargaining power & 48 & 40.00 \\
The fluctuation of feed price & 71 & 59.16 \\
\hline
\end{tabular}

Note: ${ }^{*}=$ One farmer might choose more than one constraint which is available on their farm. Number of observations was 120 . 
Table 4. The impact of social profile and constraints on the number of swine

\begin{tabular}{llll}
\hline Variables & Coefficient & SD & p-value \\
\hline Gender & -0.3497 & 0.4759 & 0.462 \\
Age & -0.3416 & 0.4043 & 0.398 \\
Experience & $1.1619^{* *}$ & 0.3263 & 0.000 \\
Formal education & $1.9832^{* *}$ & 0.3341 & 0.000 \\
Type of farming & -0.7928 & 0.5721 & 0.166 \\
Occupation & -0.7847 & 0.9774 & 0.422 \\
Family member & -0.7659 & 0.6943 & 0.184 \\
Constraints & & & \\
Capital & 0.1529 & 0.4968 & 0.758 \\
Disease outbreak & $1.4436^{*}$ & 0.5625 & 0.010 \\
Low bargaining power & -0.6182 & 0.4583 & 0.177 \\
The fluctuation of feed & $1.2656^{*}$ & 0.4948 & 0.011 \\
price & & & \\
\hline
\end{tabular}

Note: Number of observations $=120 ;$ LR chi-square $=138.24 ; \mathrm{p}>|\mathrm{z}|=$ $0.000 ;{ }^{* *}=$ significant at $(\mathrm{p}<0.001) ;{ }^{*}=$ significant $(\mathrm{p}<0.05)$.

increase in log odds of being in a higher level of the number of swine, given all of the other variables in the model were held constant. Likewise, for constraints, the coefficient of disease outbreaking and the fluctuation of feed price could imply that for a one unit change in disease outbreaking factor resulted in a 1.4436 unit change in log odds and for a one unit change in the fluctuation of feed price resulted in a 1.2656 unit change in log odds, given all of the other variables in the model were held constant. Table 4 also illustrated that farmers with a higher number of swine usually had more experience in raising swine and had higher formal education than the farmers with a lower number of swine. Additionally, the farmers who owned more swine faced risks of disease outbreak and the fluctuation of feed price higher than farmers who owned less swine.

\section{DISCUSSION}

In this study, the result of social profile in Tra Vinh Province showed that there was quite similar to the study of Assan (2014), the study of Ajala et al. (2006), and the social-demography of swine farmers in the North of Vietnam (Chau et al., 2017). Both men and women joined in swine farming activities to create profit. Male was dominant than female because the male was more powerful than female in decision making and physical ability. Most of swine farmers and their families in the study were young, and it proved that Tra Vinh Province owned high potential laborers to work on the farm. Besides, the social profile also proved that swine farmers had high education and high experience in raising swine. Therefore, some farmers combining livestock farming and cropping to earn more incomes.

In this study, the male was dominant in swine productivity in Tra Vinh Province because female prefers to cook and perform household duties as Vietnamese culture in the rural area. However, there was no effect of gender on swine herd, because male and female had the same equality in accessing swine productivity and their activities also depend on the other aspects such as farming condition factors, social-policies factors, and cultural factors. These results were also recorded in the study of Assan (2014) that young household laborers were available in Tra Vinh Province. The labor could be a potential for developing swine industry in the future who have the capabilities to gain knowledge easily. This statement was recorded by Ajala et al. (2006) that the family having more members leads to having more labors available for pig rearing activities. However, in case of swine productivity in Tra Vinh Province, there was no effect of the family member on swine herd because the family members also had the other activities to earn more income, which did not relate to farming activities. It was clear that farmers also have combined swine production and business which help them increase their incomes. These results were in line with the report of Baidoo et al. (2016) that rural farming activities required labors to undertake not only one farming activity but also various activities. Integrated agriculture and aquaculture systems have been widely applied in Vietnam and produced more benefit as the most efficient and effective models for a small farmer (Van Huong et al., 2018). However, there was also no effect on swine herd in the case of Tra Vinh Province because small swine farms or commercial swine farms had the same right to join in any type of farming and all types of farming were suitable for farmers from small scale to commercial scale of farming. Furthermore, the constraints that the farmers face were common constraints which partly affected the perception of farmers in managing swine herd when they reared swine on their farms. Those are capital, animal disease, low bargaining power, and the fluctuation of feed price. These results were similar to the findings of Chau et al. (2017). However, there was no effect of capital and bargaining power on swine herd because most of them had their own capital and the Vietnamese government has also facilitated farmers to access the available loan. Large livestock farm requires a higher level of initial investment (Do et al., 2019), but in the case of swine farming in Tra Vinh, the small farm scales were dominant and that was the reason why farmers had less constraints on capital and bargaining power.

Experience and formal education had a positive effect on the number of swine. This finding is in line with the result obtained by Phiri (2012). The farmer's characteristics, including formal education, should be considered as a crucial livestock production variable which helps farmers to have a better decision and to vary the types of farming and production systems and to adopt technologies and to control disease (Chilundo et al., 2019; Ibrahim et al., 2013; Muhanguzi et al., 2012). In addition, the level of education is also important (Racicot et al., 2012). The longer the experience of raising swine, the higher the education of farmers, the larger the number of swine kept which might be explained by the facts that when the farmers have more experience and higher education, they will know how to raise swine in the best way as well as how to manage their farms. The education and experience of farmers were associated with enhanced bio-security and disease management. However, the number of swine on the farm 
was large, it meant that the risks the farmers faced were also large. Farmers having high education and experience in raising swine could enlarge their livestock herd size effectively. Additionally, the household head has high education level, usually join in training and extension which can help them to apply new technologies or help them to have better decision making such as choosing insemination as their main breed method, which can help increase swine herd size and control disease transmission. Munyaneza et al. (2019) also showed that farmers who have high education would choose a good breeding method to be applied in their farms.

There were two main constraints that the farmers considered as factors impacting swine herd size in Tra Vinh Province, namely disease outbreak and the fluctuation of feed price. Similarly, there were main challenges faced by swine farmers, namely disease outbreak and expensive feed cost that were recorded in Motsa'a et al. (2019). Because of the disease status and the fluctuation of feed price, the decision-making process of purchasing piglets and raising swine was more complicated. Firstly, farmers were more careful in purchasing piglets from suppliers to control disease transmission to their farms. The farmer will concern and control the buying of new swine to prevent disease transmission (Suit-B et al., 2020). Secondly, farmers cannot trade their hog because of disease status. When the disease outbreak, the swine farmers face a difficult situation in raising and trading swine which could make farmers rethink whether they should raise more swine or control their swine herd size. Lindström et al. (2012) showed that disease transmission was mostly from animal movements or between-herd contacts. Besides, there was a low biosecurity level on farms which led to many difficulties in controlling diseases that were also confirmed in the North of Vietnam (Chau et al., 2017). Contagious diseases such as ASF were also confirmed in parallel with the fluctuation of feed price as problems on farm in Uganda (Muhanguzi et al., 2012). In the case of Laos, the main constraint confirmed in the farmers was the disease outbreak, similar to that, the high cost of commercial feed was mentioned as well (Phengsavanh et al., 2011). Further, the fluctuation of feed price has commonly appeared because most of feed ingredients have to be imported from the other countries. It is clear that the farmer will absolutely face the problem of fluctuation of feed price if they buy the feed which is formulated by using ingredients from abroad or imported ingredients. In the process of raising livestock, particularly in raising of swine, if the price of feed changed, but the price of hog did not change, the farmers had to protect themselves by controlling swine herd size. Especially, in 2018, Vietnam feed industry heavily depended on imported ingredients, around 65-70 percent of total raw material volume (USDA, 2019) which could increase the price of feed significantly and made a lot of swine farmers gone out of their business.

\section{CONCLUSION}

The study concluded that the farmers having higher experiences and educations kept a larger number of swine than the others. In contrary, when disease outbreak and the fluctuation of feed price emerge, farmers tended to control their swine herd sizes. Meanwhile, farmers confirmed that capital, low bargaining power, disease outbreak, and fluctuation of feed price were their current constraints on swine herd size.

\section{CONFLIC OF INTEREST}

We certify that there is no conflict of interest with any financial, personal, or other relationships with other people or organization related to the material discussed in the manuscript.

\section{ACKNOWLEDGEMENT}

We acknowledge financial support from Research Directorate of Universitas Gadjah Mada, Yogyakarta, Indonesia with Rekognisi Tugas Akhir (RTA) grant.

\section{REFERENCES}

Ajala, M. K., A. O. K. Adesehinwa, \& G. S. Bawa. 2006. Socioeconomic factors influencing swine management practices among women in jama'a local government area of Kaduna State, Nigeria [Factores socio-económicos que influyen sobre las prácticas de manejo entre mujeres productoras de cerdos en Nigeria]. Tropical and Subtropical Agroecosystems. 6: 43-48.

Assan, N. 2014. Gender disparities in livestock production and their implication for livestock productivity in Africa. Scientific J. Anim. Sci. 3: 126-138. https://doi.org/10.14196/ sjas.v3i5.1366

Baidoo, S., H. Yusif, \& U. Anwar. 2016. The effect of smallholder livestock production on income of farm households in Northern Ghana. J. Sci. Tech. 36: 8-19. https://doi. org/10.4314/just.v36i3.2

Benjamin, M. \& S. Yik. 2019. Precision livestock farming in swine welfare: A review for swine practitioners. Animals 9: 1-21. https://doi.org/10.3390/ani9040133

Chau, L. T. M., P. Lebailly, \& T. Q. Trung. 2017. Enhancing farmers' market power and income in the pig value chain; A case study in Bac Giang province, Vietnam. Livestock Research for Rural Development. 29: 1-9.www.lrrd.org/ lrrd29/12/ltmc29221.html. [6 May 2020].

Chilundo, A. G., S. Mukaratirwa, A. Pondja, S. Afonso, Z. Alfredo, E. Chato, \& M. V. Johansen. 2019. Smallholder pig farming education improved community knowledge and pig management in Angónia district, Mozambique. Trop. Anim. Health. Prod. 52: 1447-1457. https://doi. org/10.1007/s11250-019-02148-x

Do, T. L., T. T. Nguyen, \& U. Grote. 2019. Livestock production, rural poverty, and perceived shocks: Evidence from panel data for Vietnam. J. Dev. Studies. 55: 99-119. https://doi.or g/10.1080/00220388.2017.1408795

FAO. 2019. Africa swine fever (ASF) situation in Asia update, 20 September 2019. http://www.fao.org/ag/againfo/ programmes/en/empres/ASF/situation_update.html. [5 March 2020].

Fualefac, D. H., K. J. Raphae, M.-J. Bime, G. Ndebi, F. Yemele, P. A. Zoli, Y. Manjeli, A. Teguia, \& J. Tchoumboue. 2014. Socioeconomic and technical characteristics of pig farming in the urban and peri-urban zone of Dschang - West region of Cameroon. Discourse J. Agri. Food Sci. 2: 11-20.

GSO. 2016. Statistical Year Book of Vietnam 2015. Statistical Publishing House. Hanoi, Vietnam.

Haftu, B., A. Asresie, \& M. Haylom. 2014. Assessment on 
major health constraints of livestock development in eastern zone of tigray: The case of "gantaafeshum woreda" northern Ethiopia. J. Vet. Sci. Tech. : 1-9. https://doi. org/10.4172/2157-7579.1000174

Hayat, Z., M. Luqman, S. Nasir, E. Ashraf, B. Shahbaz, \& Z. Iqbal. 2017. Constraints to livestock production in the Punjab, Pakistan: a case study of District Sargodha. J. Agri. Res. 55: 213-224.

Hong Anh, P., J. J. Carrique-Mas, N. Van Cuong, N. T. Hoa, N. Lam Anh, D. T. Duy, V. B. Hien, V. T. M. Phan, M. A. Rabaa, J. Farrar, S. Baker, \& J. E. Bryant. 2014. The prevalence and genetic diversity of group A rotaviruses on pig farms in the Mekong Delta region of Vietnam. Vet. Microbio. 170: 258-265. https://doi.org/10.1016/j. vetmic.2014.02.030

Ibrahim, A. M., X. Shiwei, \& Y. Wen. 2013. The impact of social factors of rural households on livestock production and rural household income in White Nile State of Sudan. Int. J. Agri. Food Res. 2: 1-13. https://doi.org/10.24102/ijafr. v2i 4.343

Ieda, N., V. B. Quang, N. T. D. Nguyen, L. Lapar, \& K. Marshall. 2015. Characterization of smallholder pig breeding practices within a rural commune of North Central Vietnam. Trop. Ani. Health Prod. 47: 1005-1016. https:// doi.org/10.1007/s11250-015-0817-4

Lesnoff, M., S. Messad, \& X. Juanes. 2010. 12MO: A crosssectional retrospective method for estimating livestock demographic parameters in tropical small-holder farming systems. CIRAD (French Agricultural Research Centre for International Development). p. 1-51. http://livtools.cirad.fr [6 May 2020].

Lind, D. A., W. G. Marchal, \& S. A. Wathen. 2018. Statistical Techniques in Business \& Economics. $7^{\text {th }}$ ed. McGraw-Hill Education, New York.

Lindström, T., S. S. Lewerin, \& U. Wennergren. 2012. Influence on disease spread dynamics of herd characteristics in a structured livestock industry. J. Royal Society Interface. 9: 1287-1294. https://doi.org/10.1098/rsif.2011.0625

Malak-Rawlikowska, A., D. Milczarek-Andrzejewska, \& J. Falkowski. 2019. Farmers' bargaining power and input prices: What can we learn from self-reported assessments?. Social Sci. 8: 1-13. https://doi.org/10.3390/socsci8020063

Mekuriaw, Y. \& B. Asmare. 2014. Assessment of pig production and constraints in Mecha District, Amhara Region, Northwestern Ethiopia. Adv. Agri. 2014: 1-5. https://doi. org $/ 10.1155 / 2014 / 329254$

Menbere, S. 2014. Livestock production constrains priorities and its determinant factors in mixed farming system of southern Ethiopia. World J. Agri. Sci. 10: 169-177. https:// doi.org/10.5829/idosi.wjas.2014.10.4.914

Motsa'a, J. S., H. F. Defang, \& C. T. Keambou. 2019. Socioeconomic and technical characteristics of pig (Sus scrofa domesticus) production system in the humid forest with monomodal rainfall agroecological zone of Cameroon. Int. J. Biologi. Chem. Sci. 12: 2318. https://doi.org/10.4314/ijbcs. v12i5.31

Muhanguzi, D., V. Lutwama, \& F. N. Mwiine. 2012. Factors that influence pig production in Central Uganda - Case study of Nangabo Sub-County, Wakiso district. Vet. World. 5: 346-351. https://doi.org/10.5455/vetworld.2012.346-351

Munyaneza, C., V. Nyiramuhire, I. Mubashankwaya, F. Munyandamutsa, O. Ndisanze, F. Bagaragaza \& J. M. V. Mujyambere. 2019. Factors influencing success of artificial insemination of pigs using extended fresh semen in rural smallholder pig farms of Rwanda. Int. J. Livestock Prod. 10: 101-109. https://doi.org/10.5897/ijlp2018.0562

Odhiambo, C. O., C. B. Wasike, \& H. O. Ogindo. 2019. Effect of socio-demographic characteristics on Kenyan smallholder dairy farmers' adaptive strategies to climate change effects. Atmospheric and Climate Sciences. 9: 583-599. https://doi. org/10.4236/acs.2019.94037

Phengsavanh, P., B. Ogle, W. Stür, B. E. Frankow-Lindberg, \& J. E. Lindberg. 2011. Smallholder pig rearing systems in northern Lao PDR. Asian Australas. J. Ani. Sci. 24: 867-874. https://doi.org/10.5713/ajas.2011.10289

Phiri, R. E. 2012. Determination of socio-economic factors affecting piggery business in Balaka district, Malawi. Livestock Research for Rural Development. 24: 1-9. http://www.lrrd. org/lrrd24/8/phir24146.htm. [6 May 2020].

Pomar, C. \& A. Remus. 2019. Precision pig feeding: a breakthrough toward sustainability. Animal Frontiers. 9: 52-59. https://doi.org/10.1093/af/vfz006

Racicot, M., D. Venne, A. Durivage \& J. P. Vaillancourt. 2012. Evaluation of the relationship between personality traits, experience, education and biosecurity compliance on poultry farms in Québec, Canada. Preventive Vet. Med. 103: 201-207. https://doi.org/10.1016/j.prevetmed.2011.08.011

Roessler, R., S. E. Mpouam, T. Muchemwa \& E. Schlecht. 2016. Emerging development pathways of urban livestock production in rapidly growing West Africa cities. Sustainability (Switzerland). 8: 1199. https://doi.org/10.3390/su8111199

Suit-B, Y., L. Hassan, S. E. Krauss, S. Z. Ramanoon, P. T. Ooi, A. R. Yasmin, \& J. Epstein. 2020. Exploring the mental model of cattle farmers in disease prevention and control practices. Vet. Sci. 7: 27. https://doi.org/10.3390/vetsci7010027

Tabachnick, B. G. \& L. S. Fidell. 1996. Using Multivariate Statistics. $3^{\text {rd }}$ ed. Harper Collins, New York.

Thi Ly, N., T. Nanseki, \& Y. Chomei. 2016. Technical efficiency and its determinants in household pig production in Vietnam: a DEA approach. Japan. J. Rural Economics. 18: 56-61. https://doi.org/10.18480/jjre.18.56

USDA. 2019. Vietnam: Grain and Feed Annual Annual report. https://www.fas.usda.gov/data/vietnam-grain-and-feedannual-3. [6 May 2020]

Van Cuong, N., N. T. Nhung, N. H. Nghia, N. T. Mai Hoa, N. V. Trung, G. Thwaites, \& J. Carrique-Mas. 2016. Antimicrobial consumption in medicated feeds in Vietnamese pig and poultry production. EcoHealth. 13: 490-498. https://doi.org/10.1007/s10393-016-1130-z

Van Huong, N., T. H. Cuong, T. T. N. Thu, \& P. Lebailly. 2018. Efficiency of different integrated agriculture aquaculture systems in the Red River Delta of Vietnam. Sustainability (Switzerland). 10: 493. https://doi.org/10.3390/su10020493

Wang, Y. F, J. Huang, \& J. G. Zhao. 2017. Gene engineering in swine for agriculture. J. Integrative Agri. 16: 2792-2804. https://doi.org/10.1016/S2095-3119(17)61766-0 